\title{
Improving patient outcomes through perioperative nutrition support
}

\author{
AM Eisenberger ${ }^{1 *}$, J Pfeifer ${ }^{1}$, S Fuchs ${ }^{2}$, S Gabor $^{3}$ \\ From Safety in hospitals: from strategy to implementation Annual Scientific Meeting 2015 \\ Graz, Austria. 29-30 September 2015
}

\section{Background}

The primary aim in perioperative management is to reduce risks and optimize surgical outcomes for patients. Perioperative management should not only focus on operative techniques and postoperative care but include perioperative nutritional support, including adequate preoperative preparation. According to recent literature adequate perioperative nutrition leads to a decrease in complication rates, as well as decreased morbidity and mortality [1]. A recent Swiss-Austrian survey shows that nearly $80 \%$ of the senior leadership agreed, that attention to perioperative nutrition would decrease surgical complications. Only $20 \%$ of these leaders apply perioperative nutrition management. Reasons for not implementing nutritional screening and support were logistical and financial issues [2]. Therefore it was the aim of this project to standardize perioperative nutrition support at the University Hospital Graz and to facilitate perioperative nutrition management for all involved professions and to further improve patient outcomes.

\section{Materials and methods}

The interdisciplinary nutrition team of the University Hospital Graz, including dieticians, physicians, pharmacists and nurses developed a folder for perioperative nutrition management. This folder is based on the latest literature [3] and includes evidence based interventions for effective perioperative nutritional support.

\section{Results}

The folder "Perioperative Nutrition Support" includes recommendations for preoperative nutrition support, preoperative food/fluid intake and postoperative nutrition,

* Correspondence: anna.eisenberger@klinikum-graz.at

'University Hospital Graz, Auenbruggerplatz 21, 8036 Graz, Austria

Full list of author information is available at the end of the article especially for patients suffering from malnutrition. Pharmaconutrition should be applied in patients undergoing major elective surgery and patients with severe malnutrition [4]. To minimize postoperative complications carbohydrate loading should be applied to all patients undergoing elective surgery. Excluded are patients with diabetes or gastrointestinal stenosis [5]. Clear fluids, e.g. tea with/without sugar, coffee without milk or water, are allowed up to two hours before surgery. The folder also contains recommendations to early enteral feeding and oral nutrition after surgery [1].

\section{Conclusions}

To ensure patient safety as well as risk reduction in hospitalized patients undergoing surgery, perioperative nutrition support has to be part of perioperative management. Incorporation of latest nutrition research into daily practice is challenging. With implementation of the evidence based folder "Perioperative Nutrition Support" a standardized approach to improve patient outcomes with perioperative nutrition management can be achieved.

\section{Authors' details}

${ }^{1}$ University Hospital Graz, Auenbruggerplatz 21, 8036 Graz, Austria. ${ }^{2}$ Medical University of Graz, Auenbruggerplatz 22, 8036 Graz, Austria. ${ }^{3}$ Hospital Leoben-Eisenerz, Vordernbergerstraße 42, 8700 Leoben, Austria.

\section{Published: 30 October 2015}

\section{References}

1. Martindale RG, McClave SA, Taylor B, Lawson CM: Perioperative nutrition: What is the current landscape? JPEN J Parenter Enteral Nutr 2013, 37(5 Suppl):5S-20S.

2. Grass F, Cerantola $Y$, Schäfer M, Müller S, Demartines N, Hübner M: Perioperative nutrition is still a surgical orphan: results of a SwissAustrian survey. Eur J Clin Nutr 2011, 65(5):642-647.

3. Weimann A, Breitenstein S, Breuer JP, Gabor SE, Kemen M, et al: Clinical nutrition in surgery. Guidelines of the German Society for Nutritional Medicine. Chirurg 2014, 85(4):320-326. 
4. Braga M, Wischmeyer PE, Drover J, Heyland DK: Clinical evidence for pharmaconutrition in major elective surgery. JPEN J Parenter Enteral Nutr 2013, 37(5 Suppl):665-72S.

5. Wischmeyer PE, McClave SA: An evidence-based approach to perioperative nutrition support in the elective surgery patient. JPEN $J$ Parenter Enteral Nutr 2013, 37(5 Suppl):395-50S.

doi:10.1186/2056-5917-1-S1-A16

Cite this article as: Eisenberger et al: Improving patient outcomes through perioperative nutrition support. Safety in Health 2015 1(Suppl 1): A16.

Submit your next manuscript to BioMed Central and take full advantage of:

- Convenient online submission

- Thorough peer review

- No space constraints or color figure charges

- Immediate publication on acceptance

- Inclusion in PubMed, CAS, Scopus and Google Scholar

- Research which is freely available for redistribution 